\title{
Market Assessment for Residential Refrigerator-Freezer with Novel Rotating Heat Exchanger
}

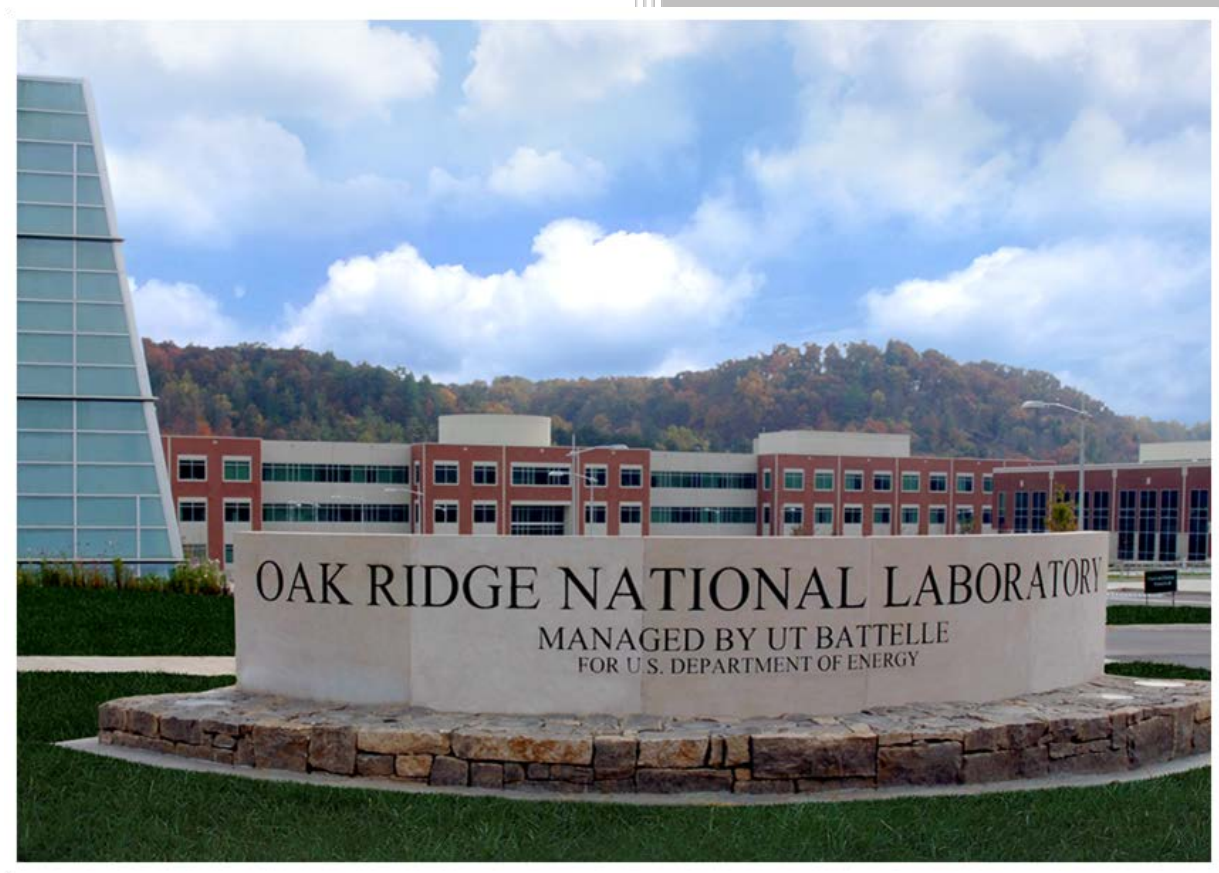

Approved for public release. Distribution is unlimited.
CSRA, Inc.

Karen Sikes

Julia Blackburn

Tyler Grubbs

ORNL

Omar Abdelaziz, Ph.D. Ayyoub Momen, Ph.D.

February 2016 


\title{
DOCUMENT AVAILABILITY
}

Reports produced after January 1, 1996, are generally available free via US Department of Energy (DOE) SciTech Connect.

\section{Website http://www.osti.gov/scitech/}

Reports produced before January 1, 1996, may be purchased by members of the public from the following source:

\author{
National Technical Information Service \\ 5285 Port Royal Road \\ Springfield, VA 22161 \\ Telephone 703-605-6000 (1-800-553-6847) \\ TDD 703-487-4639 \\ Fax 703-605-6900 \\ E-mail info@ntis.gov \\ Website http://www.ntis.gov/help/ordermethods.aspx
}

Reports are available to DOE employees, DOE contractors, Energy Technology Data Exchange representatives, and International Nuclear Information System representatives from the following source:

Office of Scientific and Technical Information

PO Box 62

Oak Ridge, TN 37831

Telephone 865-576-8401

Fax 865-576-5728

E-mail reports@osti.gov

Website http://www.osti.gov/contact.html

This report was prepared as an account of work sponsored by an agency of the United States Government. Neither the United States Government nor any agency thereof, nor any of their employees, makes any warranty, express or implied, or assumes any legal liability or responsibility for the accuracy, completeness, or usefulness of any information, apparatus, product, or process disclosed, or represents that its use would not infringe privately owned rights. Reference herein to any specific commercial product, process, or service by trade name, trademark, manufacturer, or otherwise, does not necessarily constitute or imply its endorsement, recommendation, or favoring by the United States Government or any agency thereof. The views and opinions of authors expressed herein do not necessarily state or reflect those of the United States Government or any agency thereof. 
Energy \& Transportation Science Division

Building Technologies Program

Market Assessment for Residential Refrigerator-Freezer with Novel Rotating Heat Exchanger

CSRA, Inc.

Karen Sikes

Julia Blackburn

Tyler Grubbs

ORNL

Omar Abdelaziz, Ph.D.

Ayyoub Momen, Ph.D.

Date Published: February 2016

Prepared by

OAK RIDGE NATIONAL LABORATORY

Oak Ridge, TN 37831-6283

managed by

UT-BATTELLE, LLC

for the

US DEPARTMENT OF ENERGY

under contract DE-AC05-00OR22725 



\section{CONTENTS}

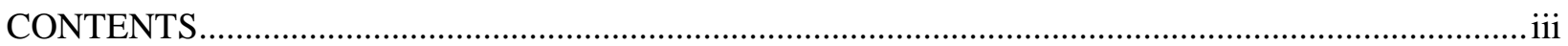

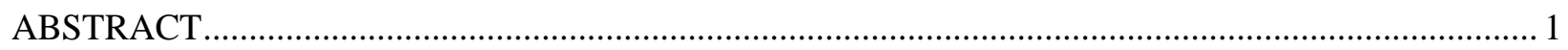

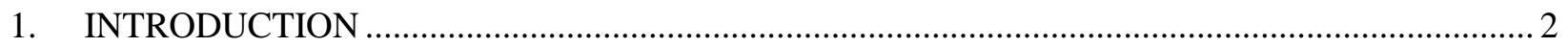

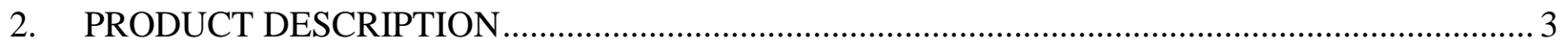

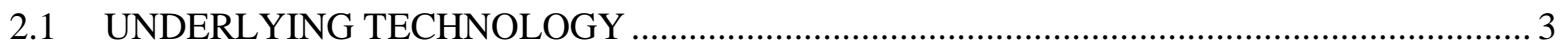

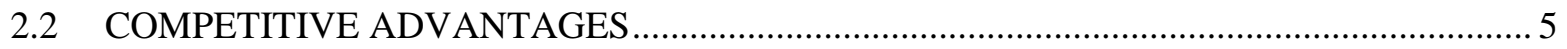

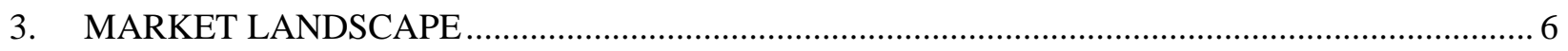

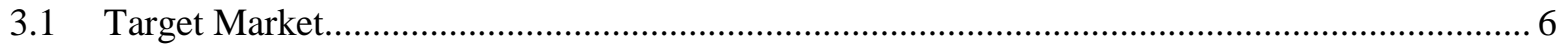

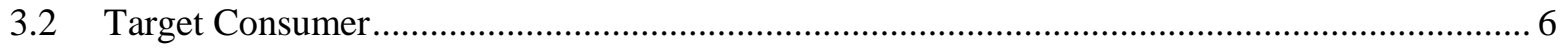

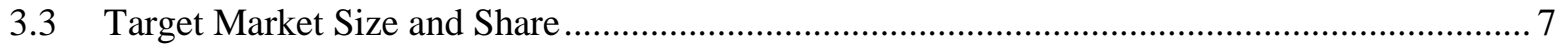

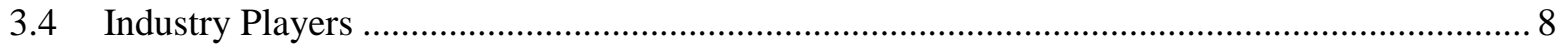

3.5 Potential Growth Drivers and Barriers to Entry ............................................................... 9

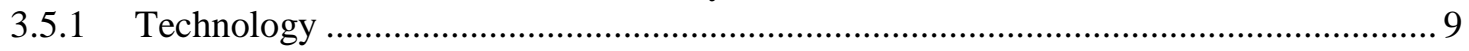

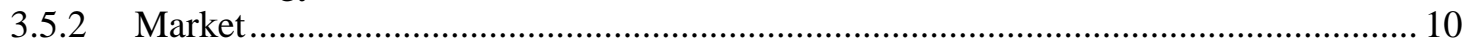

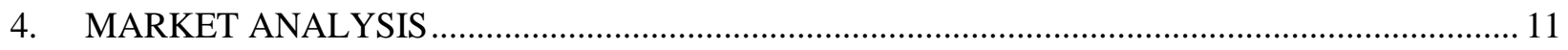

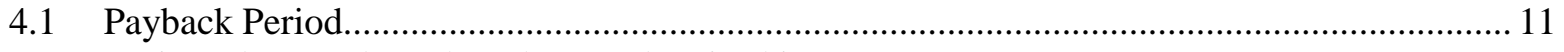

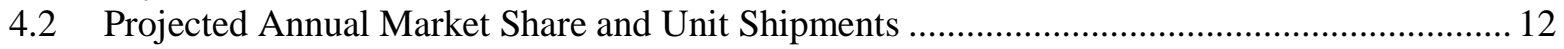

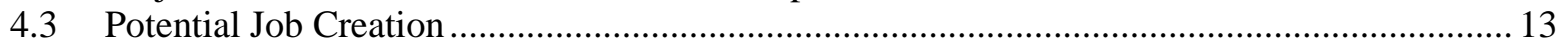

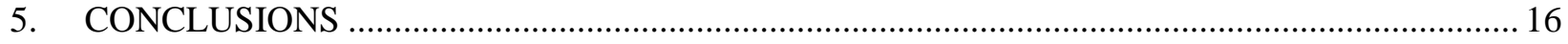

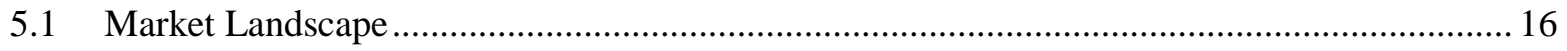

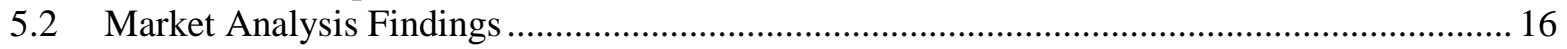

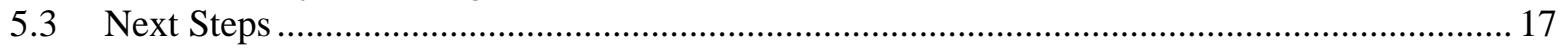

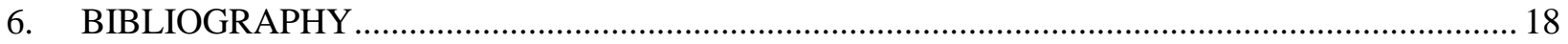

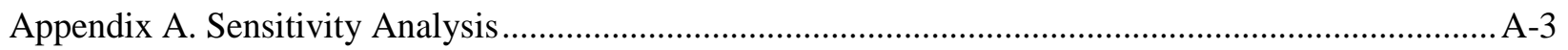


Page intentionally left blank. 


\begin{abstract}
Despite a steady record of energy efficiency improvements in residential refrigerators and freezers over recent decades, these products still account for $4 \%$ of the site energy consumption for the average U.S. household. The Oak Ridge National Laboratory (ORNL) - along with partners Sandia National Laboratories (SNL) and the University of Maryland - are pursuing further efficiency improvements in this market sector by using a novel/prototype rotating heat exchanger (RHX) based on a Sandia Cooler technology as an evaporator in a residential refrigerator-freezer. The purpose of this study is to investigate the market potential of refrigerator-freezer products equipped with RHX evaporators in the United States, including projections of maximum annual market share and unit shipments and maximum direct and indirect job creation.
\end{abstract}




\section{INTRODUCTION}

Despite a steady record of energy efficiency improvements in residential refrigerators and freezers over recent decades (U.S. Department of Energy 2012), these products still account for 4\% of the site energy consumption for the average U.S. household, according to the most recent U.S. Department of Energy (DOE) analysis (U.S. Department of Energy 2009). Previous research efforts to reduce the load of refrigerators and freezers, and contribute to more energy efficient homes, have led to advances in high performance compressors, variable speed compressors, oversized heat exchangers, better insulation, work recovery during gas expansion, and demand control frost management, but further reduction in energy consumption based on any of these components alone would be costly since they are approaching their performance limits.

Little improvement has been made in evaporators or defrost cycles in the past 40 years, but studies (Knoop, Tershak and Thieneman 1988) (Bansal, Forthergill and Fernandes 2010) (Melo, Knabben and Pereira 2013) identify defrost management as a potential area of further improvement in order to avoid additional heat gain to the refrigerated cabinet and reduce energy consumption during the defrost cycle.

The Oak Ridge National Laboratory (ORNL) - along with partners Sandia National Laboratories (SNL) and the University of Maryland - are pursuing efficiency improvements in this area by using a novel/prototype rotating heat exchanger (RHX) based on a Sandia Cooler technology as an evaporator in a residential refrigerator-freezer. This technology achieves lower energy consumption than conventional refrigerator-freezers by minimizing frost build-up and the time required to defrost it. Unlike conventional aluminum fin and tube evaporators, the centrifugal force caused by the rotating fins in the RHX evaporator results in thin frost layers that can be defrosted in seconds. In addition, the RHX evaporator's relatively small dimensions offer potential opportunities for size reduction (or increase in useable refrigerator-freezer food storage volume).

The purpose of this study is to determine whether this technology is capable of achieving market success in the United States once key economic, technological and policy drivers have been considered. In this report the authors have:

- Provided a product overview, including its underlying technology;

- Identified the competitive advantages of the product relative to comparable technologies;

- Identified the target consumer and market segment of the product;

- Identified major industry players to understand potential partners and competitors; and

- Identified potential market and technological barriers for the introduction of RHX evaporators in refrigerator-freezers.

The authors also used ORNL calculations on energy savings and payback period (based on purchase price and operating cost savings) to project:

- Maximum annual market share and unit shipments

- Maximum direct and indirect job creation

Conclusions were then drawn on the outlook of the market for refrigerator-freezers equipped with RHX evaporators in the United States, and recommendations were made for what aspects require more focus to ensure a successful market introduction and sustained growth. Factors that appear to have the greatest impact on the technology's competitiveness were also identified. 


\section{PRODUCT DESCRIPTION}

\subsection{UNDERLYING TECHNOLOGY}

As mentioned before, the technology under examination in this comparative study is a RHX serving as the evaporator in residential refrigeration applications. Refrigerators run on a vapor-compression system, which consists of a compressor, condenser, evaporator, and throttling device or expansion valve, as shown in Figure 1.

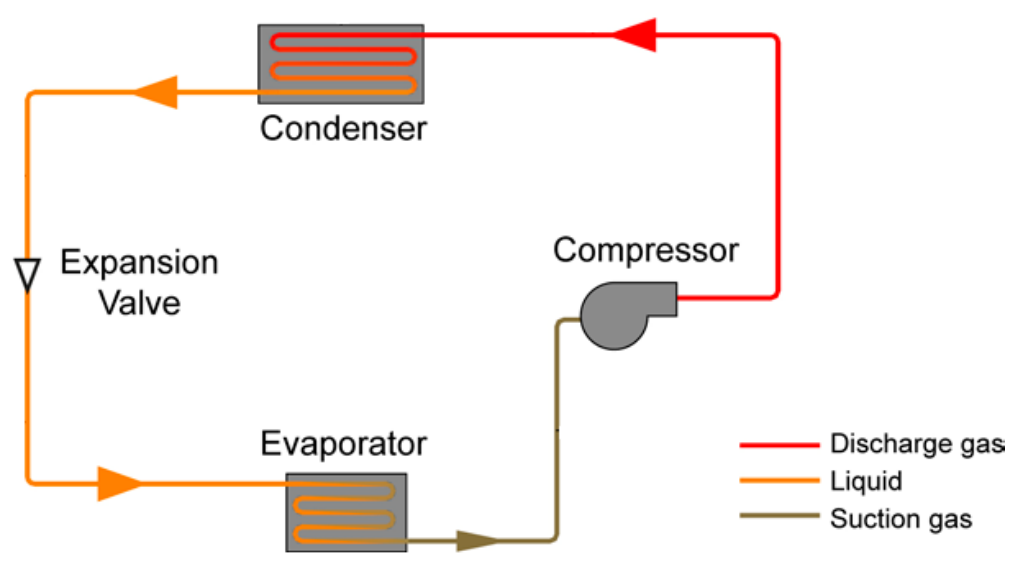

Figure 1: Basic refrigeration cycle (Reis, et al. 2015)

Refrigerant cycles continuously through these four components, absorbing and releasing heat in the process. Liquid refrigerant is passed through the evaporator in order to absorb heat from the inside of the refrigerator. As the refrigerant absorbs heat, it evaporates to form vapor. After the liquid refrigerant completely evaporates, it is sent to the compressor. Compressing the vapor increases the pressure and temperature of the gas. Leaving the compressor as a high-pressure vapor, the refrigerant is sent to the condenser. The condenser is located outside of the refrigerator. As the refrigerant passes through it, the vapor, which is at a higher temperature than the ambient air, loses heat to its surroundings. This heat loss lowers the temperature of the refrigerant and causes it to condense back into liquid form. The refrigerant now passes through a throttling device before it is returned to the evaporator. By restricting the flow of the refrigerant, the throttling device lowers the pressure of the liquid and therefore lowers its boiling point before it returns to the evaporator.

Heat exchangers are a mature technology, especially when used as a refrigerator evaporator unit. A fan blows air from the inside of the refrigerator across the evaporator. In conventional units, the refrigerant flowing through the evaporator coils absorbs heat from this air, and the efficiency of evaporators is constrained by the formation of frost on their surface. As the thickness of the frost layer grows, the ability of the evaporator to absorb heat from the inside of the refrigerator decreases. The formation of frost is the most frequent source of inefficiency in evaporator coils (Tomczyk 2013). Automatic defrost systems, comprised of a thermocouple to monitor temperature and a heater attached to the evaporator coils, must therefore be used to control the amount of frost present on the evaporator and allow it to continue absorbing heat. These systems account for approximately $15 \%$ of a refrigerator's energy consumption on average (Abdelaziz, Momen and Rice 2015).

In an RHX evaporator heat is transferred from the refrigerator-freezer cabinet through rotating impeller fins gliding on top of an air bearing gap to refrigerant flowing in tubes embedded in the baseplate (see 
schematic in left side of Figure 2). As heat is absorbed, moisture transfers onto the fins and eventually forms frost. However due to the centrifugal force exerted on the rotating fins of the RHX evaporator, only thin layers of frost form and these can be defrosted in half the time of traditional defrosting technologies. As a result, the defrost cycle energy consumption is reduced by $25 \%$, and reduces the defrost heater penalty load (Momen, Abdelaziz and Rice 2015). According to the project team, any additional frost that is formed breaks off and can be collected to subcool the refrigerant as it leaves the condenser.

SNL originally developed the Radial Sandia Cooler to serve as a heat exchanger in residential, commercial, industrial and transportation applications (Goetzler, et al. 2014). ORNL, working with SNL and the University of Maryland, used the Sandia Cooler to develop a rotating heat exchanger evaporator for residential refrigeration applications (Abdelaziz, Momen and Rice 2015). An air bearing heat exchanger, the Sandia Cooler consists of a baseplate, an impeller, and a motor to power the impeller, as shown in Figure 2.
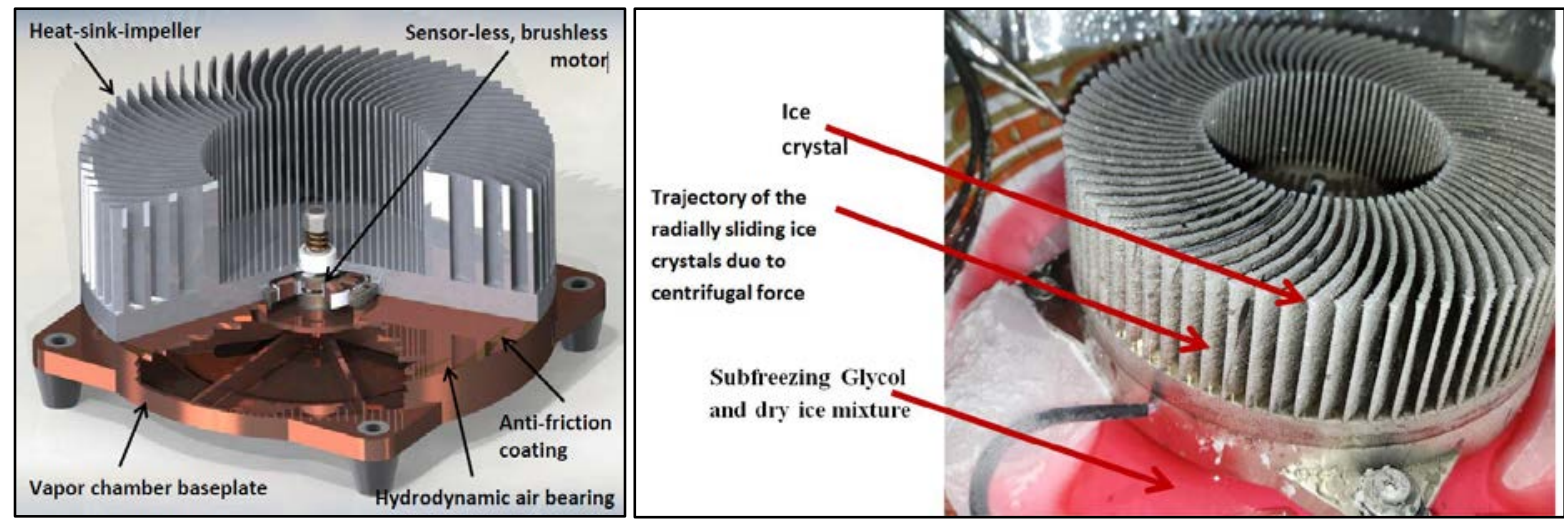

Figure 2: Sandia Cooler schematic (Johnson, et al., 2013) and actual installation showing accelerated frost accumulation testing in environmental chamber at ORNL

By improving evaporator performance, the RHX evaporator has the potential to reduce refrigerator energy use by up to 13\%, calculated using the EPA Refrigerator Analysis (ERA) software developed by Navigant Consulting (U.S. Environmental Protection Agency 1993). A number of factors contribute to the potential energy savings: increased air-side heat transfer, resistance to frost accumulation which reduces use of the defrost cycle, and the use of frost to subcool the refrigerant.

The RHX evaporator consists of a simple geometry comprised of a small number of parts and does not require any exotic materials to manufacture. This allows for low-cost, high-volume manufacturing (U.S. Department of Energy n.d.). The impellers, for example, can be cold-forged at room temperature in approximately ten seconds (U.S. Department of Energy n.d.). Testing has been conducted in a standard refrigerator-freezer with a top-mount freezer section (Figure 3), but the RHX evaporator can just as easily be integrated into bottom-mount freezer, side-by-side, and French door configurations. 


\subsection{COMPETITIVE ADVANTAGES}

The RHX technology is considered promising in the refrigeration industry because it boasts numerous competitive advantages over traditional evaporators. These include:

- $\quad$ Higher Efficiency: Due to its ability to control frost formation, reduce defrost heating, and improve heat transfer, the RHX evaporator can reduce energy use by $13 \%$ in all refrigerator models, which would equate to $65 \mathrm{kWh}$ per refrigerator (DiMascio 2014), or 13.7 TWh in energy savings, if installed in all residential refrigerators (U.S. Energy Information Administration n.d.).

- $\quad$ Lower Peak Electricity: Reduced energy consumption will lower the amount of electricity consumed during peak hours, when demand and prices are generally higher.

- Lower Emissions: Higher efficiency leads to reduced energy consumption, which typically results in fewer direct and indirect $\mathrm{CO}_{2}$ emissions.

- $\quad$ Cost Savings: The high efficiency level achieved with this technology will result in reduced consumption of electricity, therefore, reduced annual utility bills. These annual savings are expected to allow consumers to recoup the purchase

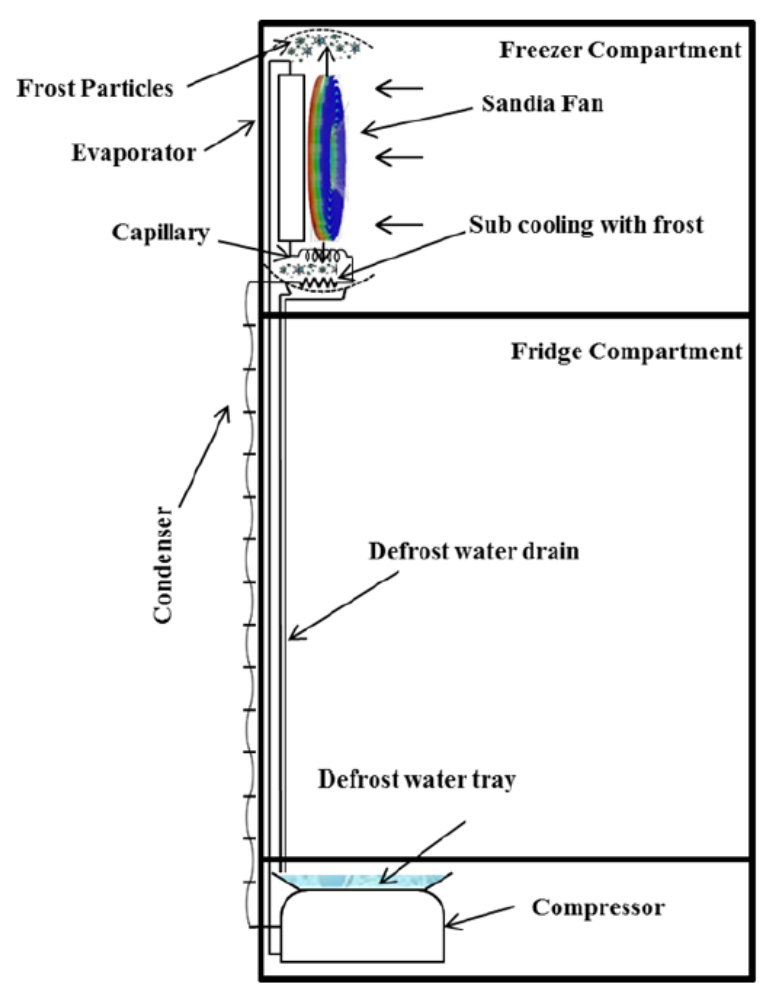

Figure 3: Schematic representation of the sideview of refrigerator with rotating $H X$ price premium within a reasonable timeframe.

- Increased Refrigerator useable storage volume: The smaller size of the RHX evaporator compared to conventional fan-plus-heat-exchanger assemblies provides opportunities to increase the usable storage volume inside refrigerator-freezer cabinets and increase in overall exterior dimensions (Goetzler, et al. 2014).

- $\quad$ Quieter refrigerator operation: The RHX evaporator operates more quietly than traditional refrigerator evaporators, reducing noise levels in the kitchen. 


\section{MARKET LANDSCAPE}

\subsection{Target Market}

The first step to understanding the market potential of a novel technology is to define the target market, which was rather straightforward in this case. Navigant Consulting's "Market Assessment and Commercialization Strategy for the Radial Sandia Cooler” (Goetzler, et al. 2014) identified residential refrigerator-freezers as one of six strong candidates for market introduction of the Sandia Cooler based on high market attractiveness and high technology attractiveness. As a result, R\&D was initiated to investigate the use of RHX evaporators in this application. Therefore, the target market in this study is assumed to be the residential refrigeration industry; more specifically, standard size household refrigerator-freezers.

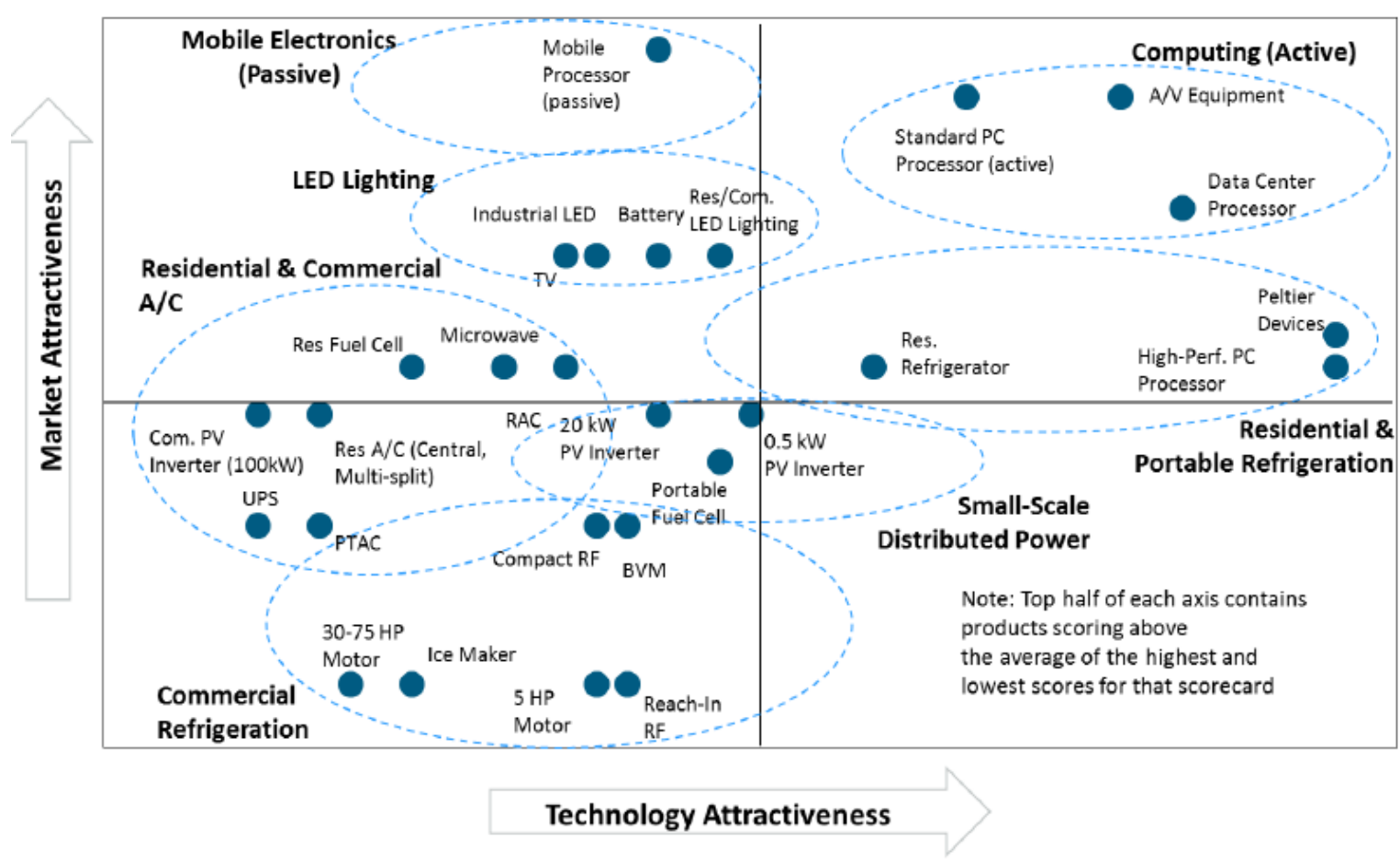

Figure 4: Scoring map for potential applications of Sandia Cooler (Goetzler, et al. 2014)

It should be noted that the Sandia report (Goetzler, et al. 2014), selected residential refrigerator-freezers as a promising market application because the authors indicated that the Sandia Cooler could help improve the performance of the condenser, which is limited by current fin-and-tube heat exchangers and dust accumulation over time. While integration into the evaporator design was not specifically mentioned, it is assumed that the capacity would be acceptable for the evaporator if the capacity is acceptable for the condenser.

\subsection{TARGET CONSUMER}

In the United States refrigerator-freezers account for 4\% of a household's energy use, offering an opportunity for new, high-efficiency evaporator technologies in residential refrigeration applications to realize substantial energy savings. 
Almost all homes have at least one refrigerator-freezer, and a growing number of households are using two. All households are considered as prospective consumers for this technology. Since these products are typically located inside in a conditioned area, the RHX evaporator is equally viable in all regions of the country.

The goal of introducing an RHX evaporator into the U.S. residential refrigerator-freezer market is to expand the overall appeal of new, high-efficiency technologies, ultimately saving consumers money on the cost of ownership over the lifetime of the appliance. Adding the technology into new refrigeratorfreezers is not expected to drive consumers to replace their existing models earlier than previously expected; instead, sales of RHX evaporator-equipped models are expected to replace traditional models as they reach their end of life or once the consumer decides it is time for an upgrade.

\subsection{TARGET MARKET SIZE AND SHARE}

Approximately 145 million residential refrigerator-freezer units are in use in the United States today, with annual sales of approximately 10 million units. Figure 5 shows how unit shipments have, for the most part, grown steadily over the past six decades, and this trend is expected to continue for several more decades (U.S. Department of Energy 2012) . This application is targeted at the entire residential refrigerator-freezer market with the potential to expand to the commercial market. According to the project team, heat exchanger requirements of this market are well matched to the RHX evaporator technology, enabling the technology to be easily adapted to this end use.

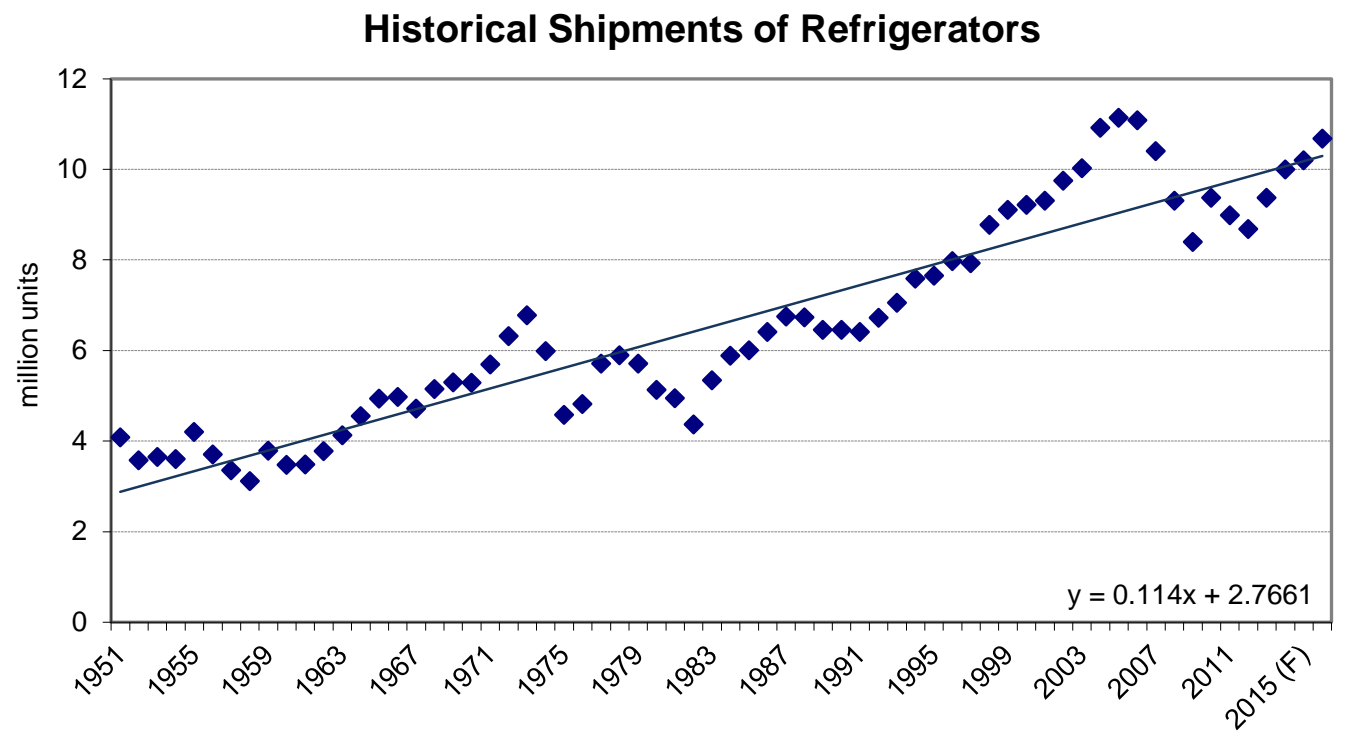

Figure 5: Unit shipments of residential refrigerator-freezers have more than doubled since 1950. [Source: Association of Home Appliance Manufacturers via (U.S. Department of Energy 2012) and (Appliance Design 2016)]

Due to the low tolerance of the residential refrigeration market for cost, the redesign costs for evaporators for current products are not expected to be accepted. Additionally, when fan motors burn out, the heat exchanger is typically not replaced, limiting the market for retrofits and replacements. Given these factors, the project team predicts that the best opportunity for the Sandia Cooler evaporator to be integrated into the market is in new refrigerator-freezer purchases.

When shopping for refrigerator-freezers, consumers are increasingly interested in the available food storage volume and energy savings a unit can offer rather than the technology that it employs. In many 
cases, consumers are faced with increasingly limited kitchen space but are accustomed to a certain usable refrigerator volume; consequently, manufacturers strive to offer higher-volume refrigerators that still meet the requirements of increasingly stringent Federal and State energy efficiency standards, as shown in Figure 6 (DiMascio 2014). Today's units consume approximately one-third of the electricity as those manufactured 30 years ago and approximately half the amount of units manufactured before 1993 when Federal standards were revised (U.S. Department of Energy 2009). As the Sandia Cooler evaporator can provide substantial gains in both of these areas, refrigerators making use of this technology are likely to appeal to consumers.

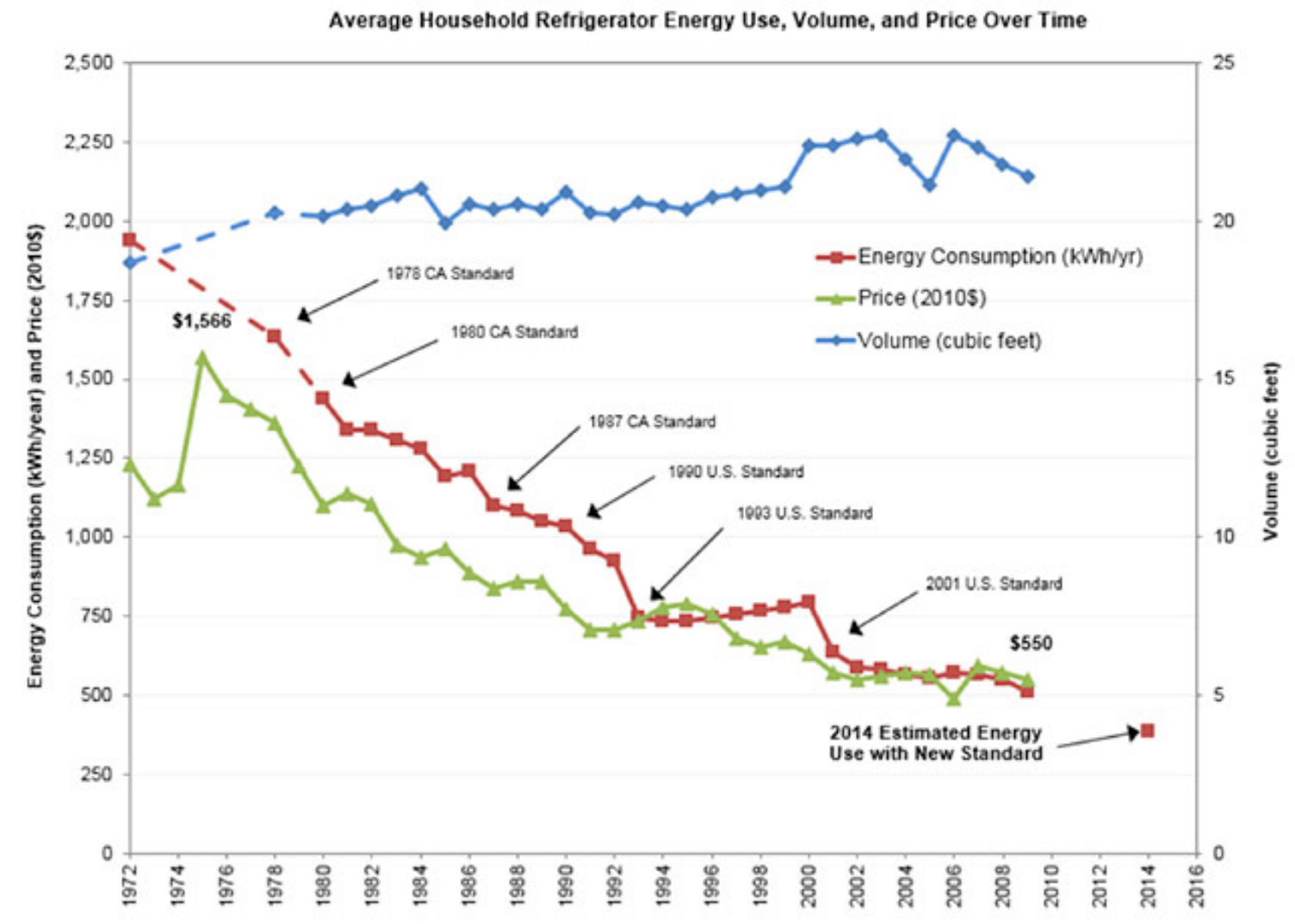

Figure 6: Despite reductions in energy use and price, refrigerator-freezer volume increased over the past four decades (DiMascio 2014)

\subsection{INDUSTRY PLAYERS}

As of 2008, the residential refrigerator-freezer market was comprised of five major companies, as shown in Figure 7. 


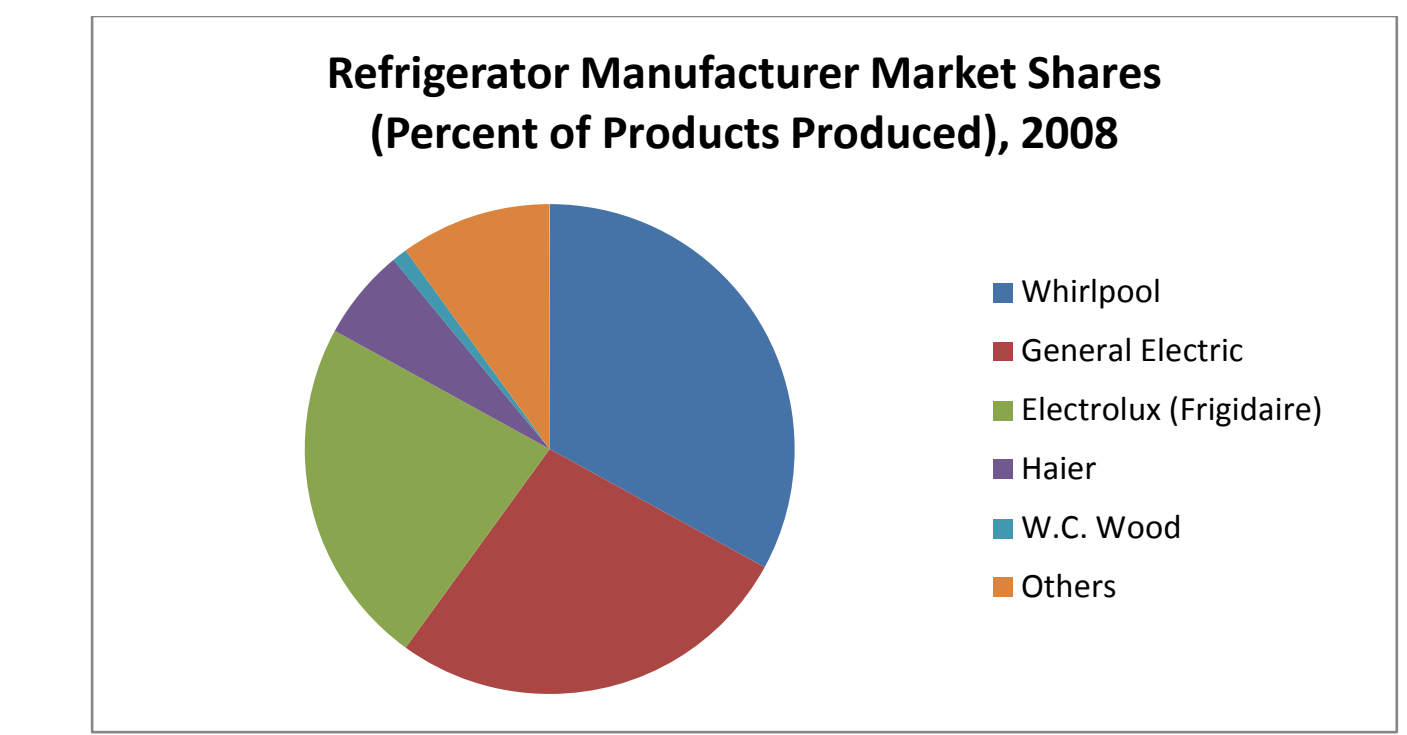

Figure 7: The residential refrigerator-freezer market is dominated by a small number of manufacturers (U.S. Department of Energy 2009)

To successfully introduce this technology into the market, ORNL should consider partnering with one of these manufacturers to commercialize the RHX evaporator. Additional manufacturers currently competing in this market include LG, Samsung, Sanyo, Miele, Bosch, and Viking.

The RHX evaporator would need to be integrated into a manufacturer's design. Manufacturers purchase heat exchangers from companies such as Brazeway, Packless, and Heatcraft to serve as condensers and evaporators. According to the project team, the design of these heat exchangers is dictated to the companies by the appliance OEMs, so this technology must receive buy-in from a manufacturer before it can compete in the residential refrigerator-freezer market.

\subsection{POTENTIAL GROWTH DRIVERS AND BARRIERS TO ENTRY}

In Chapter 2, many advantages of the Sandia Cooler evaporator are highlighted. As with most new products, these strengths are often accompanied with market risks, or barriers, to entry. If it is determined that a barrier cannot be overcome, it may even be considered a "show-stopper." Some of the expected technological and market barriers for the RHX evaporator are highlighted in the subsections below.

\subsubsection{Technology}

Technological hurdles are generally considered those that likely must be addressed through further research and development efforts, and are typically improved upon in subsequent product generations. Until then, these hurdles could significantly affect product competitiveness within the marketplace. Potential technological hurdles for the Sandia Cooler evaporator may include:

- Advanced Baseplate Design: The Sandia Cooler evaporator must be efficiently integrated into a refrigerator-freezer operating system, allowing refrigerant to flow into the Sandia Cooler baseplate.

- $\quad$ Modified Cabinet Design: Because of this market's low tolerance for cost increases, redesign costs for condensers and evaporators for current products are not likely to be accepted. 


\subsubsection{Market}

Market hurdles are generally characterized as obstacles toward achieving desired unit sales and consumer interest; even if the product and underlying technology are considered mature. Potential market hurdles for the Sandia Cooler evaporator include:

- Educating Consumers on Eventual Savings: The price premium on a refrigerator-freezer due to the integration of the RHX evaporator is estimated to be between $\$ 14$ and \$50. With new refrigerator-freezer prices running from $\$ 530$ to $\$ 1,380$ (U.S. Energy Information Administration 2015), the RHX evaporator price premium is not likely to be a significant deterrent. Regardless, manufacturers will need to convince consumers to commit to paying the upfront price premium, with the understanding that the operating cost savings accrued over the lifetime of the product will more than exceed this initial expenditure within a reasonable timeframe. To successfully argue this point, manufacturers should disseminate easy-to-convey marketing information on the product's anticipated energy savings and payback period. Retail salespersons should also be educated on these numbers and should understand why this product may or may not be the best option for their customer.

- Need for Major Manufacturer: The success of a new technology is often boosted if a major manufacturer produces one of the first models and endorses the underlying technology. Having a reputable manufacturer producing the appliance helps lessen the apprehension many consumers may associate with trying a new or early-generation technology. They also provide an established supply chain into which the technology can be integrated. Additionally, public awareness is raised when major manufacturers market new technologies, compared to a start-up company. Relevant ENERGY STAR incentives for refrigerators should also act as an incentive for major manufacturers to introduce compliant new models into the market since consumers will likely be drawn to these savings.

- Reliability: The long-term reliability of the technology has not yet been established. Since the product is still under development, the project team was only able to demonstrate one week of uninterrupted operation to date. Consumers may be hesitant to invest in technology whose longterm durability has not been proven. 


\section{MARKET ANALYSIS}

In this chapter, the market potential of refrigerator-freezers equipped with RHX evaporators will be assessed by forecasting the maximum penetration into the residential market following commercial viability, as a function of payback period (PBP).

\subsection{PAYBACK PERIOD}

The payback period estimates the amount of time (in years) it takes for the consumer to recover the assumed higher purchase cost of the more energy efficient refrigerator-freezer through lower operating costs. In this study, calculating the PBP for these refrigerators is the first step in understanding market potential since maximum unit shipment projections are dependent on this value. The PBP is calculated as the ratio of the increase in purchase cost (compared to a less-efficient baseline model) to the decrease in annual average operating cost. No discount rate to discount future operating costs is used in this calculation, shown in the following Equation:

$$
P B P=\frac{\Delta I C}{\Delta O C}
$$

Where:

$$
\begin{aligned}
& \Delta I C=\quad \text { the difference in total installed cost (IC) between the more efficient design based on a } \\
& \text { potential standard level and the base case product, and } \\
& \Delta O C=\text { the difference in annual average operating cost (OC) between the two products, in this } \\
& \text { case the reduced electricity consumption }
\end{aligned}
$$

Payback periods exceeding the life of a product mean that the increase in total installed cost is not recovered through reduced operating cost. According to DOE's final rule analyses, the average life of a standard residential refrigerator-freezer is 17 years (U.S. Department of Energy 2012).

Payback periods were calculated by the ORNL team for standard residential refrigerator-freezers equipped with RHX evaporators, relative to conventional modes with the same system operating at the same condition, resulting in a range of approximately 1.5 to 5 years:

$$
\begin{aligned}
& P B P(\text { Lower Bound })=\frac{\$ 14}{657 k W h * 13 \% * \frac{\$ 0.12}{k W h}}=1.4 \text { years } \\
& P B P(\text { Upper Bound })=\frac{\$ 50}{657 k W h * 13 \% * \frac{\$ 0.12}{k W h}}=4.9 \text { years }
\end{aligned}
$$

Where:

\footnotetext{
\$14 and \$50 = upper and lower bounds for incremental first cost of RHX refrigerator $657 \mathrm{kWh}=\quad$ energy consumed by a standard 225 Watt refrigerator-freezer operated continuously for one year, according to an interactive Department of Energy calculator (U.S. Department of Energy n.d.).

$\$ 0.12 / \mathrm{kWh}=$ national average residential electricity price
} 
$13 \%=\quad$ estimated energy consumption reduction as a result of the Sandia cooler

With R\&D still underway by the project team, the assumptions above are subject to change, and minor modifications can have significant impacts on project unit shipments and job creation. To demonstrate the level of sensitivity, a matrix is provided in Appendix A where estimated energy consumption improvements are varied from 5 to 13 percent.

\subsection{PROJECTED ANNUAL MARKET SHARE AND UNIT SHIPMENTS}

The DOE Building Technologies Program provides guidance for estimating market penetration for a new technology based on an understanding of the technical, economic, and market dynamics. One method suggested in their "Guide for Evaluation of Energy Savings Potential” (Building Technologies Program 2005) for estimating market penetration is based on payback analysis, which is illustrated in Figure 8 for HVAC equipment. (It was assumed that similar curves would exist for building appliances.)

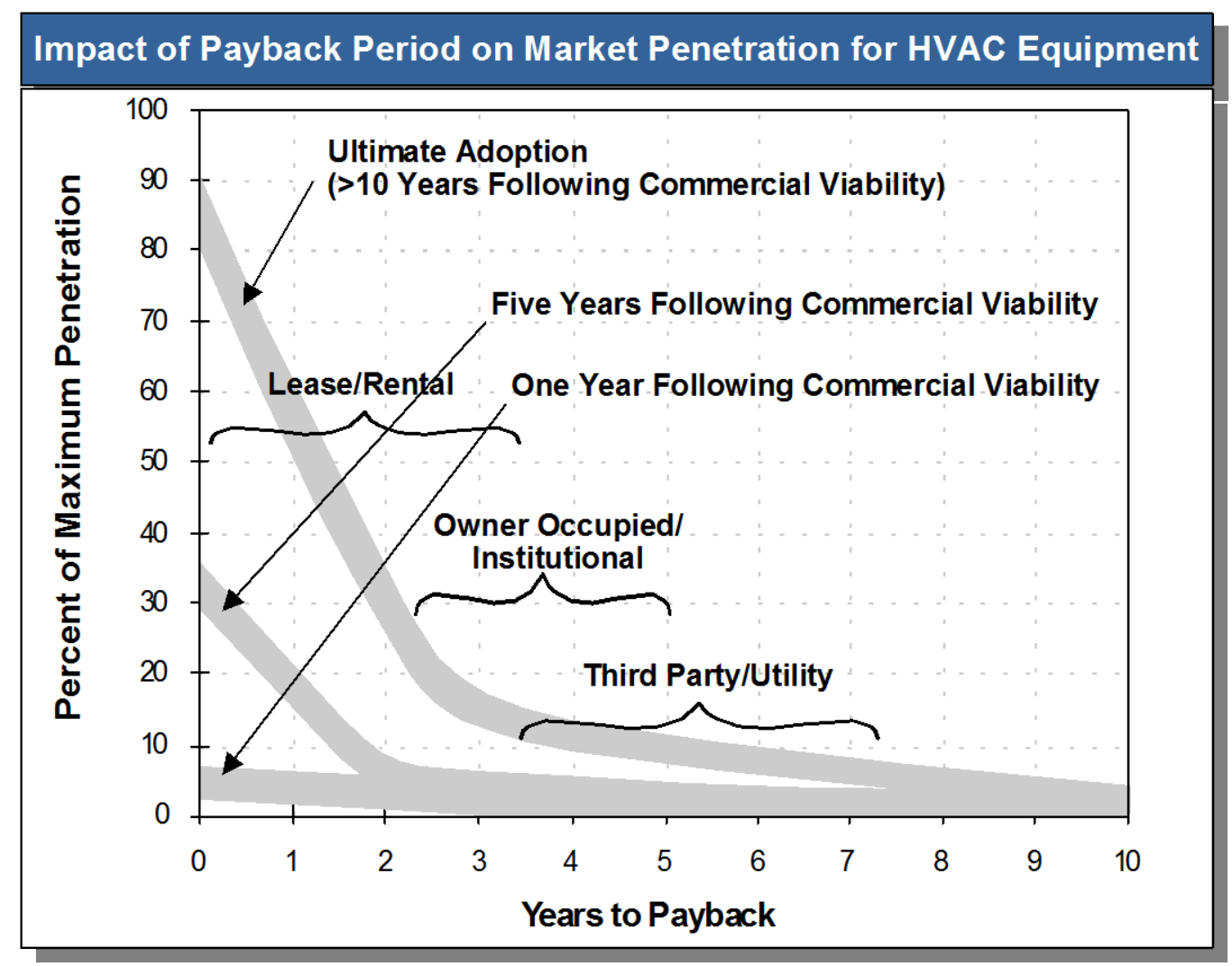

Figure 8: Relationship between payback period and market penetration for HVAC equipment at certain periods of commercial viability (Source: DOE Building Technologies Program)

Using the payback periods provided by ORNL for the RHX-equipped refrigerator-freezer and the curves in Figure 8, the maximum penetration rates into the market are estimated. These estimates are presented in Table 1. Percent ranges are provided in this table to account for the fuzziness associated with this approach, hence, the wide grey bands in Figure 8 that represent each scenario.

Using the total number of residential refrigerator-freezer shipment forecast for 2016 (10.68 million units) as a guideline for future shipments, Table 1's maximum penetration percentages can be translated into estimated maximum unit shipments at one, five, and over ten years following commercial viability. Since 
the research team provided a PBP of 1.5 to 5 years, two scenarios were analyzed to demonstrate the full range:

- $\quad \underline{\mathrm{PBP}}=1.5$ year: Maximum penetration for RHX evaporator-equipped models is estimated at 2$6 \%$ of the market, equaling roughly 210,000-640,000 annual unit shipments at one year following commercial viability. At five years following commercial viability, the maximum penetration rate increases significantly to 960,000 - 1,500,000 annual unit shipments nationwide. Maximum penetration increases to $37-48 \%$ of the market at ultimate adoption ( $>10$ years), with the upper boundary reaching approximately 5.1 million annual unit shipments.

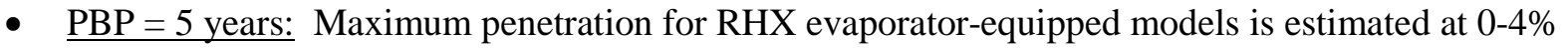
of the market, equaling roughly up to 430,000 annual unit shipments at one year following commercial viability. At five years following commercial viability, the maximum penetration rate increases moderately to 110,000-530,000 annual unit shipments nationwide. Maximum penetration increases to $8-12 \%$ of the residential refrigerator market at ultimate adoption ( $>10$ years), with the upper boundary reaching approximately 1.3 million annual unit shipments.

Table 1: Level of maximum penetration (\%) at different points in time following commercial viability

\begin{tabular}{|c|c|c|c|}
\hline \multicolumn{4}{|c|}{$\begin{array}{c}\% \text { of Max Penetration of RHX Evaporator-Equipped Refrigerator-freezers Into the } \\
\text { Residential Market }\end{array}$} \\
\hline & $\begin{array}{c}\text { One Year Following } \\
\text { Commercial } \\
\text { Viability } \\
\end{array}$ & $\begin{array}{c}\text { Five Years Following } \\
\text { Commercial } \\
\text { Viability } \\
\end{array}$ & $\begin{array}{l}\text { Ultimate Adoption } \\
\text { (>10 Years Following } \\
\text { Commercial Viability) }\end{array}$ \\
\hline 1.5 Year Payback & $2-6 \%$ & $9-14 \%$ & $37-48 \%$ \\
\hline 5 Year Payback & $0-4 \%$ & $1-5 \%$ & $8-12 \%$ \\
\hline
\end{tabular}

Table 2: Level of maximum penetration (unit shipments) at different points in time following commercial viability, based on 2016 forecasted unit shipments

Maximum Annual RHX Evaporator-Equipped Unit Shipments Into Residential Market (in thousands)

\begin{tabular}{l|c|c|c}
\hline & $\begin{array}{c}\text { One Year Following } \\
\text { Commercial } \\
\text { Viability }\end{array}$ & $\begin{array}{c}\text { Five Years Following } \\
\text { Commercial } \\
\text { Viability }\end{array}$ & $\begin{array}{c}\text { Ultimate Adoption } \\
\text { (>10 Years Following } \\
\text { Commercial Viability) }\end{array}$ \\
\hline 1.5 Year Payback & $210-640$ & $960-1,500$ & $4,000-5,100$ \\
\hline 5 Year Payback & $0-430$ & $110-530$ & $850-1,300$ \\
\hline
\end{tabular}

\subsection{POTENTIAL JOB CREATION}

In projecting potential job creation stemming from the introduction of RHX technology in residential refrigerator-freezers, we believe there to be two key determinants. First is the direct impact on those employed in manufacturing the products, and on ancillary jobs throughout the supply chain. Of secondary consideration is the economic effect of consumer utility savings arising from operational energy savings.

Direct employment impacts on relevant manufacturers are difficult to quantify and project. Investments in research and development, new or upgraded manufacturing lines, and supplier development would all support new job creation; however, production of the RHX-equipped models would slowly displace 
production of conventional models by the same manufacturers. Therefore, job creation is expected to be neutral or slightly positive provided that manufacturing occurs domestically and that automation does not displace existing manufacturing employees, though more detailed analysis would be needed to reach more concrete estimates of net job creation.

Unlike direct employment impact, the effect of operational savings on broad economic employment can be more confidently and narrowly estimated. According to the American Council for an Energy-Efficient Economy, utility savings transfer money from the energy generation and distribution industry to the general economy. The former supports 9.9 jobs per $\$ 1$ million spent, while the economy-wide average is 17.3 jobs per $\$ 1$ million spent (American Council for an Energy-Efficient Economy n.d.). Our projections assume that the difference (7.4 jobs per $\$ 1$ million in spending) can be applied to forecasting the number of jobs that may reasonably be expected to result from the adoption of more energy-efficient refrigeratorfreezers.

Projected maximum shipment volumes were calculated for periods of 1,5 and 10 years proceeding commercial viability (see Table 2), under 1.5 and 5 year payback period assumptions These estimated ranges (high value and low value) permitted the creation of four scenarios, consisting of best and worstcase projections for each payback period. In determining values for the intervening years' shipment volumes (years 2, 3, 4, 6, 7, 8 and 9) a linear growth trend was assumed to punctuate the extant values. As shown in Figure 8, market penetration accelerates with years following commercial viability, which is reflected in the 1,5 , and 10 year shipment projections.

In determining per-unit operational savings, ORNL's estimated energy reduction over the consumption of standard units was used, as well as default assumptions from the interactive Department of Energy calculator, resulting in annual energy savings per unit of \$10.25.

$$
\text { Annual Operating Cost Savings }=657 \mathrm{kWh} * 13 \% * \frac{\$ 0.12}{k W h}=\$ 10.25
$$

Where:
$657 \mathrm{kWh}=$
energy consumed by a standard 225 Watt refrigerator-freezer operated continuously for one year, according to an interactive Department of Energy calculator (U.S. Department of Energy n.d.).
$13 \%=\quad$ estimated energy savings over standard unit
$\$ 0.12 / \mathrm{kWh}=$ national average residential electricity price

Since projections extend through ten years, a multiplier was applied to reflect that units shipped during the first year would deliver ten years' worth of savings, while those shipped during the second year would deliver nine, and so on. Considering these multipliers in conjunction with per-unit savings and annual shipment volumes permitted estimates of total financial savings over the course of ten years. Assuming that such savings would support job growth per the method discussed previously in this section, the following projections were made for each scenario:

Table 3: Projected indirect job creation for RHX evaporator-equipped residential refrigerator-freezers

\begin{tabular}{l|c|c}
\hline Scenario & Maximum 10-Year Savings (\$M) & $\begin{array}{c}\text { Maximum 10-Year Job } \\
\text { Creation }\end{array}$ \\
\hline 1.5 Year Payback & $\$ 590-910$ & $4,340-6,700$ \\
\hline 5.0 Year Payback & $\$ 90-330$ & $660-2,450$ \\
\hline
\end{tabular}


To summarize, it is projected that maximum consumer utility savings could transfer between $\$ 90$ million and $\$ 910$ million from the less labor-intensive utility industry to the more intensive general economy, resulting in the creation of 660 to 6,700 indirect jobs. 


\section{CONCLUSIONS}

The objective of this study was to investigate how a residential refrigerator-freezer equipped with RHX technology might perform within the residential market in the United States. It is considered a promising technology because it boasts several competitive advantages over traditional refrigerator-freezers, including increased efficiency, increased refrigerator usable volume, and reduced operating cost.

\subsection{MARKET LANDSCAPE}

According to SNL's “Market Assessment and Commercialization Strategy for the Radial Sandia Cooler,” residential refrigeration is one of six strong candidates for market introduction of the Sandia Cooler technology, a rotating heat exchanger, based on high market attractiveness and high technology attractiveness. As a result of this study, R\&D was initiated between the partners to further investigate the in this area. Therefore, the residential refrigerator-freezer market was investigated as the target market in this study.

The target consumer/buyer of RHX evaporator-equipped models was determined to be homeowners across the United States as they would be the likely purchasers of new or replacement models. Segmentation of consumers on geographic factors is not necessary since refrigerator-freezers are needed across the country. Unit sales will most likely occur as replacements of traditional models that are approaching end-of-life or as consumers decide it is time for an upgrade. Furthermore, the market for retrofits is limited since heat exchangers are typically not replaced when fan motors burn out.

The residential refrigerator-freezer industry is a growing market, with approximately 145 million units in use today and annual sales of approximately 10 million units, dominated by roughly five major manufacturers - Whirlpool, General Electric, Electrolux, Haier, and W.C. Wood. This sizeable market presents a strong opportunity to reduce energy consumption and greenhouse gas emissions nationwide. The potential for savings would expand significantly if the use RHX technology is determined to be viable in the commercial refrigerator-freezer market.

While some technology and market barriers (e.g., price premium, yet-to-be-proven reliability and frost handling, cabinet redesign modifications) are still associated with this technology, ORNL could leverage working relationships with industry partners to transition the RHX technology into the residential market. Market analysis findings demonstrate strong potential for unit shipments and increased market share, which should appeal to top manufacturers assuming the integration of the technology is relatively straightforward and doesn't significantly impact overall design. Beyond refrigerator-freezer OEMs, suppliers (including evaporator manufacturers) would need to see value in the switch. Nevertheless, efforts to improve performance and efficiency of the existing prototype should continue in order to maximize the operating cost savings over the lifetime of the appliance, thereby, further improving payback periods.

\subsection{MARKET ANALYSIS FINDINGS}

Market analysis findings indicate that RHX-equipped refrigerator-freezers show strong market potential within the residential market. Using calculations provided by the ORNL team on energy savings and anticipated price premiums, payback periods could be calculated, which range from 1.5 to 5 years. These payback periods were then translated into maximum annual unit shipments for RHX evaporator-equipped models using the DOE Building Technologies Program's “Guide for Evaluation of Energy Savings Potential, resulting in the following values:

- $\quad \mathrm{PBP}=1.5$ years 
o Up to 640,000 annual unit shipments at one year following commercial viability;

o Up to 1.5 million annual unit shipments at five years following commercial viability; and

o Up to 5.1 million annual unit shipments at ultimate adoption (>10 years following commercial viability).

- $\quad \mathrm{PBP}=5$ years

o Up to 430,000 annual unit shipments at one year following commercial viability;

o Up to 530,000 annual unit shipments at five years following commercial viability; and

o Up to 1.3 million annual unit shipments at ultimate adoption (>10 years following commercial viability).

In the best case scenario, RHX evaporator-equipped models could capture up to $48 \%$ of the total market at ultimate adoption ( $>10$ years following commercial viability); worse case, they capture up to $8 \%$. The wide range here is linked to the uncertainty in price premium associated with the RHX technology, resulting in the uncertainty in payback periods. Regardless, it is important to remember that percentages representative the maximum market penetration, so actual market penetration will likely far below these projections.

The combination in unit shipment projections and annual cost savings was used to project job creation, both direct and indirect, tied to the introduction of RHX evaporator-equipped refrigerator-freezers. As discussed, direct job creation is expected to be neutral or slightly positive provided that manufacturing occurs domestically and that automation does not displace existing manufacturing employees. Indirect job creation estimates were more quantitative since they were directly tied to utility savings, which transfer money from the energy generation and distribution industry to the general economy to create new jobs. Calculations showed that the maximum consumer utility savings could transfer between $\$ 90$ million and $\$ 910$ million from the less labor-intensive utility industry to the more intensive general economy, resulting in the creation of 660 to 6,700 indirect jobs.

\subsection{NEXT STEPS}

As outlined in Task 7.0's Deliverable 3.2, the next step is to identify potential appliance manufacturing partner for commercialization as well as potential manufacturers of system components. Initial qualities to consider when seeking the right partner(s) for commercialization include:

- A reputable, well-established manufacturer in the residential refrigeration industry capable of relatively easily incorporating this design change into existing plant lines;

- Ability to capitalize on their industry position to endorse/promote new products, lessening the apprehension many consumers may associate with trying a new or early-generation technology, and raise public awareness regarding the technological, energy-saving, and environmental benefits of this product;

- Strong brand recognition, reputation of quality appliances, widespread presence, and appealing design aesthetic; and

- Positive experience working with a national laboratory during the $\mathrm{R} \& \mathrm{D}$ and/or licensing phases. 


\section{BIBLIOGRAPHY}

Abdelaziz, Omar, Ayyoub Momen, and Keith Rice. "Conference Paper Session 14 - Heat Transfer Research: Novel Frost Handling Techniques Using Air Bearing Heat Exchangers for Household Refrigerators." ASHRAE 2015 Annual Conference. 2015.

American Council for an Energy-Efficient Economy. "Energy Efficiency and Economy Opportunity." American Council for an Energy-Efficient Economy. n.d. http://aceee.org/files/pdf/fact-sheet/eeeconomic-opportunity.pdf (accessed June 2015).

Appliance Design. Forecasts/Shipments Archives. 2016. http://www.appliancedesign.com/ForecastShipmentArchives.

Bansal, P., D. Forthergill, and R. Fernandes. "Thermal analysis of the defrost cycle in a domestic freezer." International Journal of Refrigeration 33, no. 3 (2010): 589-599.

Building Technologies Program. "Guide for Evaluation of Energy Savings Potential." Office of Energy Efficiency and Renewable Energy, U.S. Department of Energy, 2005.

DiMascio, Marianne. "How your refrigerator has kept its cool over 40 years of efficiency improvements." ACEEE Blog. Edited by American Council for an Energy-Efficient Economy. September 11, 2014.

Goetzler, William, Richard Shandross, Daniel Weintraub, and Jim Young. Market Assessment and Commercialization Strategy for the Radial Sandia Cooler. Burlington, MA: Navigant Consulting, Inc., 2014.

Knoop, D., A. Tershak, and M. Thieneman. "An Adaptive Demand Defrost and Two-Zone Control and Monitor System for Refrigeration Products." IEEE Transactions on Industry Applications 24, no. 2 (1988): 337-342.

Melo, C., F. Knabben, and P. Pereira. "An experimental study on defrost heaters applied to frost-free household refrigerators." Applied Thermal Engineering 51, no. 1-2 (2013): 239-245.

Momen, Ayyoub M., Omar Abdelaziz, and Keith Rice. "Novel Frost Handling Techniques Using Air Bearing Heat Exchangers for Household Refrigerators." ASHRAE Transactions 121, no. 2 (2015): 1.

Reis, Chuck, Eric Nelson, James Armer, Tim Johnson, Adam Hirsch, and lan Doebber. Refrigeration Playbook: Heat Reclaim - Optimizing Heat Rejection and Refrigeration Heat Reclaim for Supermarket Energy Conservation. Technical Report, CTA Architects Engineers and the National Renewable Energy Laboratory, Golden, Colorado: National Renewable Energy Laboratory, 2015.

Tomczyk, John. The Professor: Controlling Evaporator, Defrost Efficiency. April 1, 2013. http://www.achrnews.com/articles/122863-the-professor-controlling-evaporator-defrostefficiency. 
U.S. Department of Energy. Buildings Energy Data Book. 2009. http://buildingsdatabook.eren.doe.gov.

U.S. Department of Energy. ENERGY STAR Refrigerator Market Profile 2009. 2009.

-. Estimating Appliance and Home Electronic Energy Use Web . n.d. http://energy.gov/energysaver/estimating-appliance-and-home-electronic-energy-use (accessed February 1, 2016).

-. High-Performance Refrigerator Using Novel Rotating Heat Exchanger. n.d. http://energy.gov/eere/buildings/downloads/high-performance-refrigerator-using-novelrotating-heat-exchanger (accessed January 19, 2016).

U.S. Department of Energy. Residential Refrigerator and Freezer Final Rule Technical Support Document. Washington, D.C.: U.S. Department of Energy, 2012.

U.S. Energy Information Administration. Residential Sector Key Indicators and Consumption, Reference Case. n.d. http://www.eia.gov/oiaf/aeo/tablebrowser/\#release=AEO2015\&subject=2AEO2015\&table=4-AEO2015\&region=0-0\&cases=ref2015-d021915a.

—. Updated Buildings Sector Appliance and Equipment Costs and Efficiencies. April 2015. http://www.eia.gov/analysis/studies/buildings/equipcosts/pdf/full.pdf.

U.S. Environmental Protection Agency. "EPA Refrigerator Analysis Program (ERA): User's Manual." 1993. 
Page intentionally left blank. 
APPENDIX A. SENSITIVITY ANALYSIS 
Page intentionally left blank. 


\section{APPENDIX A. SENSITIVITY ANALYSIS}

The matrix in Table 4 demonstrates the sensitivity of unit shipment and job creation projections when energy consumption improvements are varied from 5 to 13 percent. The same overall approach defined in Chapter 4 was used in this sensitivity analysis.

Table 4: Demonstration of how unit shipment and job creation projections are impacted by energy consumption improvements

\begin{tabular}{|c|c|c|c|c|c|c|c|c|c|c|}
\hline & & \multirow{2}{*}{ PBP (years)* } & \multicolumn{3}{|c|}{$\begin{array}{c}\text { Max Penetration into Residential Market } \\
\text { at Certain Levels of Commercial } \\
\text { Viability }\end{array}$} & \multicolumn{3}{|c|}{$\begin{array}{l}\text { Max Unit Shipments at Certain Levels } \\
\text { of Commercial Viability (in thousands) }\end{array}$} & \multicolumn{2}{|c|}{ Job Creation } \\
\hline & & & 1 Year & 5 Years & $\begin{array}{l}>10 \text { Years } \\
\text { (ult. adoption) }\end{array}$ & 1 Year & 5 Years & $\begin{array}{l}>10 \text { Years } \\
\text { (ult. adoption) }\end{array}$ & $\begin{array}{l}\text { Max 10-Year } \\
\text { Savings (in } \\
\text { millions) }\end{array}$ & $\begin{array}{l}\text { Max 10-Year } \\
\text { Indirect Jobs }\end{array}$ \\
\hline \multirow{18}{*}{ 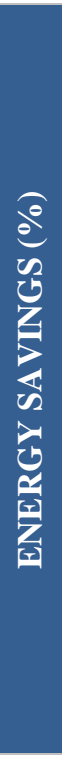 } & \multirow{2}{*}{5} & Lower: 3.6 & $0-4 \%$ & $2-6 \%$ & $11-15 \%$ & $0-430$ & $210-640$ & $1,200-1,600$ & $\$ 141-381$ & $1,040-2,820$ \\
\hline & & Upper: 12.7 & - & - & - & - & - & - & - & - \\
\hline & \multirow{2}{*}{6} & Lower: 3.0 & $0-5 \%$ & $2-7 \%$ & $13-18 \%$ & $0-530$ & $210-750$ & $1,400-1,900$ & $\$ 155-455$ & $1,150-3,360$ \\
\hline & & Upper: 10.6 & - & - & - & - & - & - & - & - \\
\hline & \multirow{2}{*}{7} & Lower: 2.5 & $1-5 \%$ & $3-7 \%$ & $17-23 \%$ & $110-530$ & $320-750$ & $1,800-2,500$ & $\$ 238-498$ & $1,760-3,680$ \\
\hline & & Upper: 9.1 & $0-2 \%$ & $0-2 \%$ & $2-6 \%$ & $0-210$ & $0-210$ & $210-640$ & $\$ 15-149$ & $110-1,100$ \\
\hline & \multirow{2}{*}{8} & Lower: 2.2 & $1-5 \%$ & $4-8 \%$ & $22-30 \%$ & $110-530$ & $430-850$ & $2,300-3,200$ & $\$ 303-574$ & $2,240-4,250$ \\
\hline & & Upper: 7.9 & $0-2 \%$ & $0-3 \%$ & $3-7 \%$ & $0-210$ & $0-320$ & $320-750$ & $\$ 23-186$ & $170-1,380$ \\
\hline & \multirow{2}{*}{9} & Lower: 2.0 & $1-5 \%$ & $5-9 \%$ & $26-35 \%$ & $110-530$ & $430-960$ & $2,800-3,700$ & $\$ 339-639$ & $2,500-4,730$ \\
\hline & & Upper: 7.0 & $0-3 \%$ & $0-4 \%$ & $5-9 \%$ & $0-320$ & $0-430$ & $530-960$ & $\$ 38-255$ & $280-1,890$ \\
\hline & \multirow{2}{*}{10} & Lower: 1.8 & $2-6 \%$ & $6-11 \%$ & $30-40 \%$ & $210-640$ & $640-1,200$ & $3,200-4,300$ & $\$ 445-761$ & $3,300-5,700$ \\
\hline & & Upper: 6.3 & $0-3 \%$ & $0-4 \%$ & $6-10 \%$ & $0-320$ & $0-430$ & $640-1,100$ & $\$ 46-265$ & $340-1,960$ \\
\hline & \multirow{2}{*}{11} & Lower: 1.6 & $2-6 \%$ & $8-13 \%$ & $35-46 \%$ & $210-640$ & $850-1,400$ & $3,700-4,900$ & $\$ 536-865$ & $3,970-6,400$ \\
\hline & & Upper: 5.8 & $0-3 \%$ & $0-4 \%$ & $7-10 \%$ & $0-320$ & $0-430$ & $750-1,100$ & $\$ 54-265$ & $340-1,960$ \\
\hline & \multirow{2}{*}{12} & Lower: 1.5 & $2-6 \%$ & $9-14 \%$ & $36-47 \%$ & $210-640$ & $960-1,500$ & $3,800-5,000$ & $\$ 572-898$ & $4,230-6,650$ \\
\hline & & Upper: 5.3 & $0-4 \%$ & $1-5 \%$ & $8-11 \%$ & $0-430$ & $110-530$ & $850-1,200$ & $\$ 90-324$ & $660-2,400$ \\
\hline & \multirow{2}{*}{13} & Lower: 1.4 & $2-6 \%$ & $9-14 \%$ & $37-48 \%$ & $210-640$ & $960-1,500$ & $4,000-5,100$ & $\$ 586-906$ & $4,340-6,700$ \\
\hline & & Upper: 4.9 & $0-4 \%$ & $1-5 \%$ & $8-12 \%$ & $0-430$ & $110-530$ & $850-1,300$ & $\$ 90-331$ & $660-2,450$ \\
\hline
\end{tabular}

* Lower PBP uses $\$ 14$ as the $\triangle \mathrm{IC}$; upper PBP uses $\$ 50$ as the $\Delta \mathrm{IC}$; see Chapter 4 for more information. 